\title{
Structural and physicochemical properties of freeze-dried açaí pulp (Euterpe oleracea Mart.)
}

\author{
Aryane Ribeiro OLIVEIRA ${ }^{1}$, Alline Emannuele Chaves RIBEIRO ${ }^{2}$, Érica Resende OLIVEIRA ${ }^{1,3 *}$ (D), \\ Marina Costa GARCIA ${ }^{1}$, Manoel Soares SOARES JÚNIOR ${ }^{1,4}$, Márcio CALIARI ${ }^{1}$
}

\begin{abstract}
The objective of this study was to characterize the structural and physicochemical properties, the bioactive compounds and the antioxidant activity of freeze-dried açaí pulp (FDAP). The morphology of freeze-dried açaí pulp showed a continuous matrix with a spongey aspect, and the X-ray diffractometry indicated that $96.17 \%$ of the molecular structure was in the amorphous state and $3.82 \%$ in the crystalline state. Freeze-dried açaí pulp presented an interesting chemical composition of macronutrients, which constituted mainly of lipids (49.14 g/100 g d.b.), proteins $(9.19 \mathrm{~g} / 100 \mathrm{~g}$ d.b.), total crude fiber $(20.29 \mathrm{~g} / 100 \mathrm{~g}$ d.b.) and total sugars (2.71 g/100 g d.b.). It also showed great amount of total phenolic compounds (1405.03 $\mathrm{mg}$ gallic acid/100 $\mathrm{g}$ d.b.) and anthocyanins (127 mg cyanidine-3-glucoside/100 g d.b.), allowing for functional properties allegations. There was significant increase in the water absorption and water solubility indices when the freeze-dried açaí pulp was submitted to a gradual increase in temperature, properties that are adequate for industrial use. Thus, the consumption of freeze-dried açaí pulp should be encouraged and also its use by the food industry in order to develop new food products.
\end{abstract}

Keywords: scanning electron microscopy; infrared; differential scanning calorimetry; x-ray diffractometry; phenolic compounds.

Practical Application: The traditional way of commercializing açaí pulp is in the regular frozen form. However, the elevated moisture content can be reduced by the freeze-drying process, decreasing both the volume and the mass of the product, making transportation easier, and allowing its application as an ingredient in the formulation of different types of food. Freeze drying could also be an alternative to protect the nutrients and bioactive compounds of açaí pulp from degradation.

\section{Introduction}

Açaí tree (Euterpe oleracea) is a palm native to the Amazon region, and belongs to the Arecaceae family. Its distribution is predominantly tropical and subtropical, and the largest natural reserves of this palm tree can be found in the state of Pará, Brazil. The fruit, also denominated as açaí, is a globous, fibrous berry, $0.5 \mathrm{~cm}$ in diameter, dark violet in color, containing an edible oleaginous pulp (Caldeira Silva et al., 2016; Costa et al., 2015). The national and international growth in the consumption of açaí in the last decade can be attributed to the greater knowledge of the nutritional properties of this fruit, since it is rich in protein, fiber, and lipid (Engels, 2010; World Resources Institute, 2017; Menezes et al., 2008; Yamaguchi et al., 2015). In addition to the nutritional properties, the fruit has expressive amounts of a distinct class of flavonoids, the anthocyanins, which confer antioxidant properties to the fruit (Santos et al., 2014; Yamaguchi et al., 2015). These pigments are highly unstable during storage and processing. Thus, the food industry is searching for processes that may increase the shelf life of açaí and improve the stability of anthocyanin compounds (Arslan,
2015). The traditional way of commercializing açaí pulp, both on the internal and external markets, is in the frozen form. However, the high moisture content $(89.9 \mathrm{~g} / 100 \mathrm{~g})$ could be reduced by the freeze drying process, which allows decreasing both the volume and the mass of the product, making transportation easier, and its application as an ingredient in the formulation of different types of food (Gaidhani et al., 2015). Freeze drying is a food drying type of process that uses sublimation under vacuum at low temperatures. This method was developed to reduce the losses of nutrients and compounds responsible for food aromas, which are susceptible to the processing modalities that use high temperatures, such as conventional drying (Rajkumar et al., 2017). Freeze drying could be an alternative to protect the nutrients and bioactive compounds of açaí pulp from degradation. Thus, the objective of this study was to assess the structural and physicochemical properties, the bioactive compounds and the antioxidant activity of freeze-dried açaí pulp (FDAP), and provide relevant information on the potential of FDAP as a food ingredient for the food industry. 


\section{Materials and methods}

\subsection{Raw material and processing of freeze-dried açaí pulp (FDAP)}

The açaí pulp was acquired at the local market in the the city of São Luís (MA, Brazil) and stored in polyethylene packaging for the purpose of freeze drying. Before freeze drying, the pulp $(1 \mathrm{~kg})$ was placed on the stainless steel trays of the freeze-dryer (Liotop, L101, São Carlos, Brazil) and frozen (ColdLab, CL347-80, Piracicaba, Brazil) at $-40{ }^{\circ} \mathrm{C}$ for $24 \mathrm{~h}$. The trays were then transferred to the freeze-dryer and the vacuum turned on, so that part of the free water of the pulp could be sublimed off. This process took an average of $72 \mathrm{~h}$ at a pressure of $138 \mathrm{mmHg}$. The condenser temperature was at $-51{ }^{\circ} \mathrm{C}$. Each freeze-dried sample was homogenized in an industrial blender (Vitalex, LQI-02, Catanduva, Brazil), packed in metallized polyethylene pouches, and placed in a freezer at $-18^{\circ} \mathrm{C}$ until further analysis.

\subsection{Structural and thermal properties}

\section{Granulometry}

The particle size was determined using a sieve shaker (Bertel, 4819, Caieiras, Brazil). A sample of $100 \mathrm{~g}$ of powder was sieved through the set of sieves $(0.841,0.250,0.149,0.105$ and $0.074 \mathrm{~mm}$ mesh) according with Virginia Department of Transportation (2015). The sample was placed on the top sieve with the largest mesh size followed by the smaller ones and shaken for $10 \mathrm{~min}$. The material retained by each sieve and that in the base were weighed and expressed as percentages, which were used to calculate the fineness modulus (FM) (South African Bureau of Standards, 1990; Virginia Department of Transportation, 2015), the particle mean diameter (PMD) and the uniformity index (UI). PMD was calculated through the Henderson \& Perry (1976) equation (Equation 1), which was adapted in order to present the results in $\mu \mathrm{m}$. In order to calculate the UI, the percentage of retained particles $(\mathrm{R})$ in each type of sieve (coarse, regular, and fine) was previously determined. Then, the UI was given as the sum of each type of particle size individually, meaning that, there is an UI for coarse, regular, and fine particles (Equation 2).

$$
\begin{aligned}
& P M D(m)=104.14 \times 2^{F M} \\
& U I(\%)=\frac{\sum R}{10} \times 100
\end{aligned}
$$

\section{Scanning Electron Microscopy (SEM)}

The freeze-dried products were fixed onto stubs with double-sided carbon tape. The aluminum support was sputter-coated under vacuum with a thin film of metallic gold using a Bal-Tec model SCD 050 evaporator (Balzers, Liechtenstein). A nanotechnology system scanning electron microscope (Jeol, JSM - 6610, São Paulo, Brazil) was used with an accelerating voltage of $20 \mathrm{kV}$ and a working distance of $9 \mathrm{~mm}$ to obtain digital images using the Leo User Interface software at varying magnifications (300x and 1500x). The images were processed using Corel Draw 14 Photo-Paint Software.
Fourier Transform Infrared absorption spectroscopy (FTIR)

A spectroscope (Bomem Hartmann \& Braun, MB 102, Quebec, Canadá) was used and the operating conditions were established as: $400-4000 \mathrm{~cm}^{-1}$ with 32 sweeps and resolution of $2 \mathrm{~cm}^{-1}$. To prepare the pellets, $1 \mathrm{mg}$ of each sample was mixed with $100 \mathrm{mg}$ of $\mathrm{KBr}$ and pressed between two plates under high pressure (approximately eight tons) until the formation of a translucent pellet with no deformation.

\section{$X$-ray diffraction and relative crystallinity}

The X-ray diffraction standard was obtained using a bench diffractometer (Arl-Zeiss, URD6, Jena, Germany). The measurement range was from $10^{\circ}$ to $40^{\circ}$ with a speed of $0.45^{\circ} \mathrm{min}^{-1}$ at $35 \mathrm{kV}$ and $15 \mathrm{~mA}$, with $\mathrm{Cu}$-ka radiation $(\lambda=1.5406 \AA)$. The relative crystallinity was calculated from the ratio between the peak areas and the total area of the diffractograms according to the method described by Nara \& Komiya (1983) and Origin software (Microcal Inc., Origin 7.5, Northamptom, USA).

\section{Thermal properties}

Differential scanning calorimetry (DSC) (TA Instruments, Q20, New Castle, UK) was used to assess the thermal properties of FDAP. FDAP suspensions in water $(1: 3 \mathrm{w} / \mathrm{w})$ were sealed in an aluminum sample holder and maintained at room temperature for $12 \mathrm{~h}$ before the analysis. An empty sample holder was used as the reference. The samples were heated from 35 to $100^{\circ} \mathrm{C}$ at a rate of $10^{\circ} \mathrm{C} / \mathrm{min}$. The transition temperatures (initial, peak, and final) and the variation in enthalpy $(\Delta \mathrm{H})$ of FDAP were determined during heating with the aid of the TA Universal Analysis applicative (TA Instruments, New Castle, UK).

\subsection{Color and physicochemical properties}

\section{Instrumental color}

The color was analyzed using a colorimeter (Minolta, BC-10, Ramsey, USA) calibrated with a white porcelain surface so as to obtain the standard. The following parameters were then read: luminosity $\left(\mathrm{L}^{*}\right)$ and the color coordinates $\mathrm{a}^{\star}$ and $\mathrm{b}^{*}$. The parameters of chroma (color saturation) and hue angle (tonality or matrix) were further calculated as described by McGuire (1992).

\section{Chemical composition, energy value, water activity, $\mathrm{pH}$ and acidity}

Moisture content was quantified by desiccation to constant weight at $105^{\circ} \mathrm{C}$ in an oven with air circulation. Ash content was assessed by weighing the samples after incineration at $550{ }^{\circ} \mathrm{C}$ in a muffle furnace. Nitrogen content was determined by the micro-Kjeldahl method, and multiplied by a factor of 6.25 to obtain the crude protein content. Lipids were extracted with petroleum ether P.A. using a Soxhlet apparatus. Total dietary fiber content was determined using the defatted sample, following the enzymatic-gravimetric method. Total carbohydrate content was calculated by difference, subtracting the sum of moisture, protein, lipid, fiber, and ash contents from 100. Total energy value was obtained by multiplying carbohydrates and protein 
contents by 4 and the lipid content by 9 and adding them up. Water activity was determined using a digital bench apparatus (Decagon Devices, Inc., AquaLab Series 3 TE, Washington, USA), and the $\mathrm{pH}$ value using a $\mathrm{pH}$ meter (Tecnal, TEC-51, Piracicaba, Brazil). Total titratable acidity was obtained by titrating the samples with $\mathrm{NaOH}(0.1 \mathrm{~mol} / \mathrm{L})$. All the analyzes were carried out according to the recommendations of the Association of Official Analytical Chemists (2016). Total and reducing sugars were determined following the methodology of Miller (1959). All the results are presented in a dry weight basis (d.b.).

\section{Bioactive compounds and antioxidant activity}

Extracts for the phenolic and antioxidant assays were obtained by the method described by Brand-Williams et al. (1995), using methanol (50\% v/v) and acetone $(70 \% \mathrm{v} / \mathrm{v})$ as the extracting solvents. Total phenolic content was quantified by the Folin-Ciocalteau's method as described by Singleton \& Rossi (1965). Antioxidant capacity was determined by the DPPH (2,2 diphenyl-1-picrylhydrazyl) free radical scavenging method, according to Brand-Williams et al. (1995). Total monomeric anthocyanin content was assessed through the differential $\mathrm{pH}$ method (Wrolstad et al., 2005).

\section{Water Solubility (WSI), Water Absorption (WAI) and Oil Absorption (OAI) Indices}

All the indices were determined according to Anderson et al. (1970), the first two being determined at $25,60,70,80$ and $90^{\circ} \mathrm{C}$, whereas OAI was only determined at $25^{\circ} \mathrm{C}$. In order to determine OAI, the water was substituted by soy oil.

\subsection{Statistical analysis}

In this study, the experiment was carried out three times in different days and the analyzes were assessed at least in triplicate, with three repetitions each. Data obtained for WSI and WAI at different temperatures were analyzed through the analysis of variance (ANOVA), and averages were compared by the Tukey's test $(\mathrm{p}<0.05)$. All statistical analyzes were carried out using the software Statistica 10.0 (StatSoft Inc., 2010).

\section{Results and discussion}

\subsection{Structure and thermal properties of freeze-dried açaí pulp (FDAP)}

The particle size of the raw material is a relevant aspect in the elaboration of food products. Better quality products can be obtained when the particle size is uniform, mainly due to better water absorption and distribution within the structure of the product, an aspect observed in FDAP. Besides, the particle size influences directly on flours and powdered products' physicochemical properties (Hidalgo et al., 2014).

The FM calculated was 4.97 , the mean particle diameter was $3.28 \mathrm{~mm}$, and the UI was (9:0:1) (coarse: regular: fine) indicating that the particles were very homogeneous, with the majority of the larger FDAP particles (93.58\%) being retained on the $0.842 \mathrm{~mm}$ sieve and the majority of the fine particles on the $0.25 \mathrm{~mm}$ sieve.

FDAP particles presented misshapen lamellar forms (Figure 1A) with spongey appearance, due to the large amount of micropores (Figure 1B).

This was coherent with what is expected for freeze-dried products, since microscopic capillaries are formed during removal of the water, caused by the sublimation of ice crystals. This characteristic is related to the greater water absorption capacity of the product (Ishwarya et al., 2015).

FTIR absorption spectrum showed evidence of various functional groups in the organic structure of FDAP (Figure 2).

The intense, wide peak between the wavelengths of $3200 \mathrm{~cm}^{-1}$ and $3600 \mathrm{~cm}^{-1}$ is related to stretching of the $\mathrm{O}-\mathrm{H}$ bond present in the water molecule, whereas the intense peaks between $2831 \mathrm{~cm}^{-1}$ and $2977 \mathrm{~cm}^{-1}$ correspond to stretching of the C-H bond, probably, $\mathrm{CH}_{2}$ fragments from the fatty acids, and also to stretching of the $\mathrm{NH}_{3}$ of amino acids (Anjos et al., 2015; Pereira et al., 2015).

The band at the wavelength of $1748 \mathrm{~cm}^{-1}$ could be associated with the stretching of $\mathrm{C}=\mathrm{O}$ bond (Figure 2), a grouping present in oleic acid, which constitutes the greater part of the fatty acids present

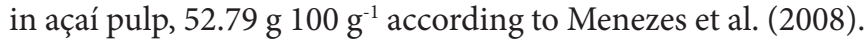
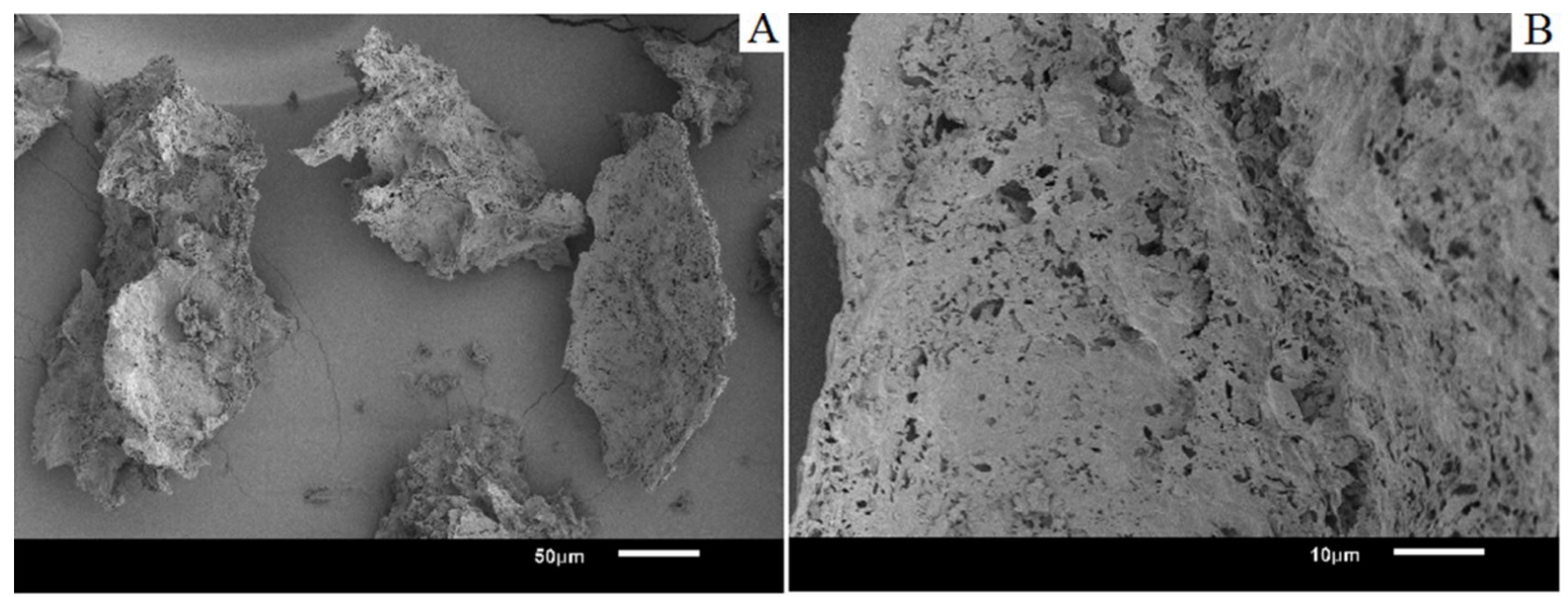

Figure 1. Scanning electron micrographs of freeze-dried açaí pulp (FDAP). (A) FDAP (x300); (B) FDAP (x800). 


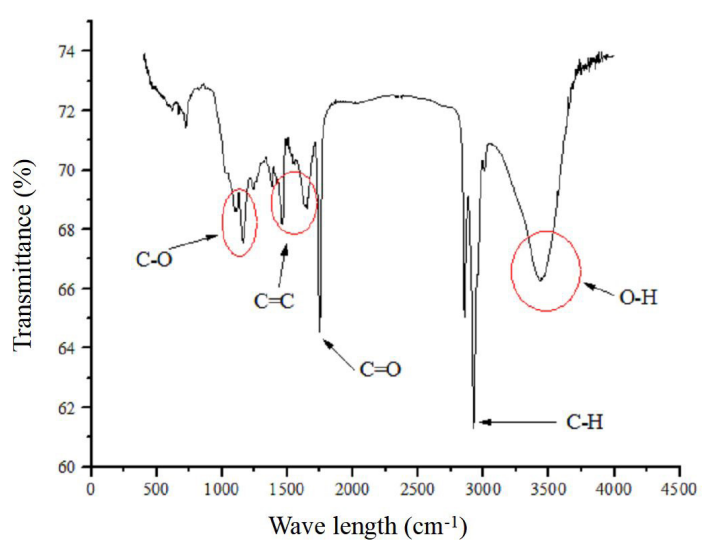

Figure 2. Fourier transform infrared absorption spectrum of the freeze-dried açaí pulp.

The region of the band close to $1760 \mathrm{~cm}^{-1}$ is related to the $\mathrm{C}=\mathrm{O}$ bond of saturated components (Núñez-Sánchez et al., 2016), probably palmitic acid, present in large amounts in FDAP

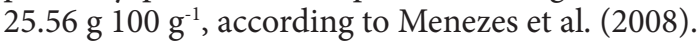

Vibration of the wavelength $1614 \mathrm{~cm}^{-1}$ is associated with the oscillation of $\mathrm{C}=\mathrm{C}$ double bonds, which are typical of aromatic compounds, probably of phenolic compounds and anthocyanins (Abbas et al., 2017; Chen et al., 2018; Oliveira et al., 2011), both present in FDAP (Table 1).

The wavelengths between 1200 and $1500 \mathrm{~cm}^{-1}$ configured a mixed region, containing bands corresponding to fatty acids, proteins and polysaccharides. On the other hand, the region between 957 and $1200 \mathrm{~cm}^{-1}$ was associated with stretching of the $\mathrm{C}-\mathrm{O}$ bond of the polysaccharides, sugars (fructose and glucose), esters and organic acids, as reported by Musingarabwi et al. (2016).

The greater part of FDAP was in the amorphous condition (96.17\%), represented by a wide, diffuse peak on the diffractogram (Figure 3).

However, FDAP also presented a high intensity peak at an angle of $21.01^{\circ}$ and a low intensity peak at $24.4^{\circ}$. These angles were close to those commonly found in diffractograms of crystallized sucrose, glucose and fructose, suggesting that the freeze drying process reached the conditions required for the formation of these crystals (Nurhadi et al., 2018).

Harnkarnsujarit \& Charoenrein (2011) evaluated the behavior of freeze-dried mango pulp after seven days of storage at $25^{\circ} \mathrm{C}$, and found crystallinity peaks similar to those found in the present study. The crystallization of sugars in freeze-dried products is desirable, since crystalline sugars make water adsorption difficult and are consequently less hygroscopic, obtaining powdered products that are more stable under different atmospheric conditions (Mensink et al., 2017), an advantage observed in FDAP.

The DSC curve of FDAP showed a subtle change in the heat flow, starting at $53.28^{\circ} \mathrm{C}\left(\mathrm{T}_{\text {on }}\right)$, with a peak at $60.16^{\circ} \mathrm{C}\left(\mathrm{T}_{\mathrm{p}}\right)$, finishing at $71.41^{\circ} \mathrm{C}\left(\mathrm{T}_{\text {in }}\right)$ with gelatinization enthalpy $(\Delta \mathrm{H})$ of $0.49 \mathrm{~J} / \mathrm{g}$ (Figure 4 ).

This result corroborates to those of the X-ray, which showed a typical peak of an amorphous material (Figure 3), and the subtle peak visualized on the thermogram could be explained by the small amount of crystalline material present in FDAP.

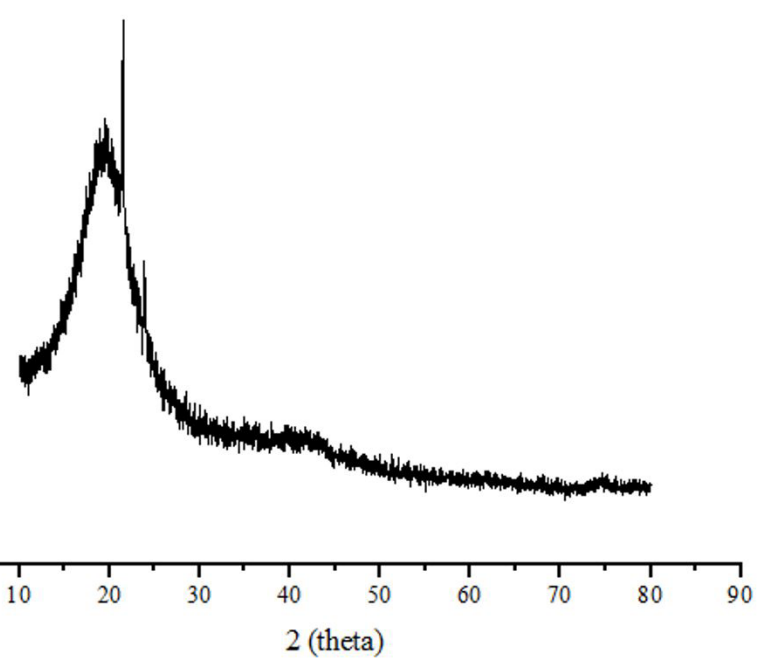

Figure 3. X-ray diffractogram of freeze-dried açaí pulp at $25^{\circ} \mathrm{C}$.

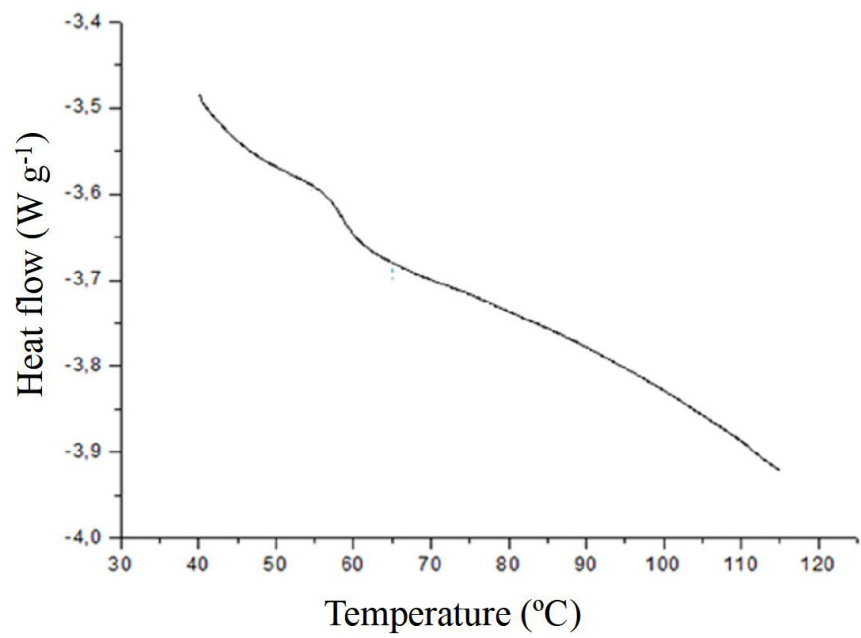

Figure 4. Differential scanning calorimetry curve of freeze-dried açaí pulp.

Table 1. Physical and chemical composition (d.b.), bioactive compounds and antioxidant activity of the freeze-dried açaí pulp (FDAP).

\begin{tabular}{lc}
\hline \multicolumn{1}{c}{ Parameters } & FDAP \\
\hline Moisture $(\mathrm{g} / 100 \mathrm{~g})$ & $5.68 \pm 0.14$ \\
Protein $(\mathrm{g} / 100 \mathrm{~g})$ & $9.19 \pm 0.01$ \\
Lipid $(\mathrm{g} / 100 \mathrm{~g})$ & $49.14 \pm 0.36$ \\
Ash $(\mathrm{g} / 100 \mathrm{~g})$ & $5.16 \pm 0.09$ \\
Total dietary fiber $(\mathrm{g} / 100 \mathrm{~g})$ & $20.29 \pm 0.14$ \\
Total carbohydrates $(\mathrm{g} / 100 \mathrm{~g})$ & $36.6 \pm 0.06$ \\
Energy value $(\mathrm{kcal} / 100 \mathrm{~g})$ & $591.8 \pm 4.12$ \\
Total sugar $(\mathrm{g} / 100 \mathrm{~g})$ & $2.71 \pm 0.04$ \\
Reducing sugar $(\mathrm{g} / 100 \mathrm{~g})$ & $1.7 \pm 0.1$ \\
pH & $5.51 \pm 0.04$ \\
Titrable acidity (g/100 g) & $1.03 \pm 0.01$ \\
Total phenolic compounds (mg gallic acid/100 g) & $1405.03 \pm 1.8$ \\
Monomeric anthocyanins & $127 \pm 6.23$ \\
(mg cyanidin-3-glucoside/100 g) & \\
DPPH scavenging capacity $(\%)$ & $41.5 \pm 0.75$ \\
\hline
\end{tabular}

Data are mean followed by standard deviation $(n=9)$. 


\subsection{Color and physicochemical properties}

\section{Instrumental color}

The mean value obtained for $\mathrm{L}^{\star}(29.53 \pm 0.44)$ indicated that FDAP was dark in color, since $L^{*}$ represents how light or dark the sample is, varying from 100 (white) to zero (black). With respect to the coordinates $\mathrm{a}^{*}$ and $\mathrm{b}^{*}$, the pulp showed low values $(-0.5 \pm 0.02$ and $3.39 \pm 0.08$, respectively), indicating a tonality tending slightly to red. These results were expected since the pulp was rich in anthocyanins, a pigment responsible for orange, red, blue and violet colorations in different fruits and flowers (Eng Khoo et al., 2017). The mean value obtained for $\mathrm{H}^{\star}(351.24 \pm 0.15)$ confirmed that FDAP was in the color range of red and blue, representing purple. The value found for $C^{*}(3.43 \pm 0.09)$ indicated a purer and saturated purple color. Siqueira et al. (2018) obtained values for $L^{\star}, C^{\star}$ and $\mathrm{H}^{\star}$ of $9.5,35.5$, and 48.7 respectively, representing a pulp associated with a dark reddish saturated tone (black).

\section{Chemical composition and energy value}

Table 1 shows the physical and chemical composition and the energy values obtained in this study for FDAP.

FDAP presented low mean values for moisture content and water activity (Table 1). Freeze drying was efficient as it reduced the moisture content and water activity of the pulp, restricting the possibility of the occurrence of many chemical and biochemical reactions, and guaranteeing a stable pulp from the microbiological point of view. The low water activity $(<0.2)$ could favor autoxidation of the lipids in FDAP. However, the presence of compounds with antioxidant capacity in the same pulp was a positive factor in retarding such chemical reactions (Nimse \& Pal, 2015). FDAP is constituted of almost 50\% lipids (Table 1), characterizing it as a food with high energy density. The values obtained for lipid content corroborate with those reported by Fregonesi et al. (2010), who found lipid values in the range of 24.75 to $56.60 \mathrm{~g} / 100 \mathrm{~g}$ (d.b.) when evaluating different labels of frozen açaí pulps, and explained the large variation on the basis of different harvesting times, maturation stages, and water volumes used to extract the pulps.

Protein content found in FDAP (Table 1) was higher (42.5\%) than that reported by Castro et al. (2014), of $5.28 \mathrm{~g} / 100 \mathrm{~g}$. FDAP protein content is much higher than that of the majority of fruits commonly present in a regular diet of an adult, such as avocado $(1.27 \mathrm{~g} / 100 \mathrm{~g})$ (Daiuto et al., 2014). Ash content found in FDAP (Table 1) was within the range reported by Neida \& Elba (2007), who evaluated açaí at different harvesting times and obtained values between 2.2 and $5.2 \mathrm{~g} / 100 \mathrm{~g}$. Such values correspond to the mineral compounds content present in the sample, indicating that FDAP is rich in these components.

FDAP presented relatively little total carbohydrates content in relation to the majority of fruits, from which $55.4 \%$ represents total dietary fiber, and $7.4 \%$ is total sugars (Table1). Total dietary fiber content of FDAP was high compared to the pulp of other pigment-rich fruits, such as jambolan $(2.28 \mathrm{~g} / 100 \mathrm{~g})$, acerola (1.85 g/100 g) and grape (1.12 g/100 g) (Lago et al., 2006). Total dietary fiber content found in FDAP was within the range reported by Neida \& Elba (2007) for in natura açaí (20 to $30.9 \mathrm{~g} / 100 \mathrm{~g}$ (d.b.)), and below that reported by Alexandre et al. (2004) (31.37 g/100 g (d.b.)). Hence, FDAP can be considered as an excellent source of fiber. Fibers, in addition to providing nutritional and physiological benefits, can improve some of the technological properties of foods, such as the water and oil absorption capacities, emulsification properties, and reinforcement of the structure and mechanical properties of biodegradable films, amongst others (Montalvo-González et al., 2018).

FDAP reducing and total sugar contents are presented on Table 1. The presence of sugars has nutritional importance and it is also important to the acceptance of in natura and processed fruits and to their potential fermentative capacity. Coutinho et al. (2017) evaluated different trademarks of frozen açaí pulps from Minas Gerais and Pará states (Brazil) and reported reducing and non-reducing sugars contents ranging from 0.17 to $1.09 \mathrm{~g} / 100 \mathrm{~g}$ and from 0.06 to $0.47 \mathrm{~g} / 100 \mathrm{~g}$, respectively. The result observed in this study for reducing sugar content was $\sim 56 \%$ higher than the upper limit observed by the latter authors. $\mathrm{pH}$ of FDAP (Table 1) was similar to that observed by Siqueira et al. (2018) (5.16) for the same fruit. However, the same authors observed a much lower titrable acidity for this fruit $(0.19 \mathrm{~g} / 100 \mathrm{~g})$ compared to this study (Table 1). pH data is important for color analysis, since the anthocyanic compounds present different colors depending on the $\mathrm{pH}$ of the medium (Siqueira et al., 2018). pH and titrable acidity were within Brazilian legislation limits ( $\mathrm{pH}$ ranging from 4 to 6.2, and maximum acidity of $0.4 \mathrm{~g} / 100 \mathrm{~g}$ ) (Brasil, 2000).

Borges et al. (2011), while studying different açaí cultivars, observed that variations in chemical composition are considered natural, since the material under study is of vegetable origin, and it is, therefore, influenced by genotype, soil, climatic conditions, harvesting period, pulping process, storage conditions, and also by the analytical conditions adopted.

\section{Bioactive compounds and antioxidant activity}

Berries, such as açaí, are acknowledged by their high amount of antioxidant molecules. These chemical compounds are a group of secondary metabolites that prevent the fruit from oxidation due to environmental factors, such as light, air, oxygen, and microbiological attacks. Phenolic antioxidants interfere with the oxidation process as free radical terminators and sometimes also as metal chelators (Hidalgo \& Almajano, 2017). Phenolic compounds or polyphenols are a group of hydroxylated molecules very susceptible to oxidation. They were found to have various biological properties, such as anti-proliferative, anti-diabetic, anticancer, anti-microbial, anti-inflammatory, antiviral, and antioxidant (Bhanja Dey et al., 2016). They have different structures but in general contain an aromatic ring with one or more hydroxyl groups (Hidalgo \& Almajano, 2017).

FDAP presented high amount of total phenolic compounds (TPC) (Table 1) when compared to fruits that are considered source of these nutrients, such as blueberries (77.26 to $215.12 \mathrm{mg}$ gallic acid/100 g) (Okan et al., 2018). The high values obtained for TPC could result from interference of other reducing substances, such as ascorbic acid or reducing sugars 
(Bessada et al., 2015). Silveira et al. (2017) reported lower TPC content (419 to $1,017 \mathrm{mg}$ gallic acid/100 g (d.b.)) for freeze-dried white açaí juice than that found in the present research, as well as Garzón et al. (2017), who found $607 \mathrm{mg}$ gallic acid/100 g w.b. in Colombian pasteurized frozen açaí pulp. According to Moura et al. (2018), the main phenolic compounds found in açaí were myricetin, epicatechin, catequin, and rutin, which are directly related to the antioxidant capacity of the fruit. According to Yamaguchi et al. (2015), among the phenolic compounds present in açaí, anthocyanins stand out as the main class, cyanidine-3-glucoside and cyanidine-3-rutinoside being the predominant forms, representing $30 \%$ of TPC, and being responsible for the purple color of the fruit. The monomeric anthocyanin content found in FDAP was lower (Table 1) than that reported by Moura et al. (2018), who optimized anthocyanin extraction conditions from açaí pulp (410.24 mg/100 g (d.b.)) and blueberries $(874.17 \mathrm{mg} / 100 \mathrm{~g}$ (d.b.)). Anthocyanin content, TPC content and, consequently, the antioxidant capacity can vary according to the environmental conditions, seasonal factors, handling of the culture, cultivation factors and vegetable genetic factors (Liu et al., 2016). In fact, quantification of anthocyanins can be a tool to assess the maturation index. The increase in anthocyanin pigments is an important quality parameter to be evaluated in açaí fruits, since it is directly related to a greater or smaller presence of red pigmentation in the skin and pulp of the fruit (Sablani, 2015). The radical scavenging capacity of FDAP (Table 1) reached $41.5 \%$, which is lower than that reported by Castillo et al. (2013) (74.5\%). Garzón et al. (2017) assessed the antioxidant activity through the DPPH method for Colombian açaí berries and reported 21,049 $\mu \mathrm{mol}$ trolox/100 g (d.b.), and Moura et al. (2018) reported an $\mathrm{EC}_{50}$ of $0.62 \mathrm{mg} / \mathrm{mL}$. The presence of antioxidants in a product or food is very important since these compounds are capable of inhibiting or decreasing the effects unleashed by free radicals, thus, preventing diseases, such as cancer, heart disease and cataract (Leopold, 2015).

\section{Water solubility index and water and oil absorption indices}

WSI is a representative of product behavior in an aqueous phase and a criteria for determining reconstitution quality of the powder. For consumers, quick and complete reconstitution of powdered products is one of the main quality indicators. Solubility of powders can be affected by many parameters, such as initial compositions of the raw material and temperature (Jafari et al., 2017). There was a significant increase $(\mathrm{p}<0.05)$ in WAI and WSI with increase in temperature as from $60^{\circ} \mathrm{C}$ (Table 2).

This increase was expected since an increase in temperature may cause conformational changes in the starch, protein and fiber molecules present in FDAP, exposing their hydrophilic groups $(-\mathrm{OH})$ and making their bonding to water easier (Lili et al., 2015). At room temperature, WAI value was higher than that of oil (OAI) (Table 2), probably because there were slightly more hydrophilic groups, as it can be seen on the infrared absorption spectrum (Figure 3). Jafari et al. (2017) observed that increasing temperature levels caused a little raise in WSI of spray-dried pomegranate juice powder, which may be, according to the authors, the result of lower density as a consequence of higher temperature and that larger particles rapidly sink in water, while
Table 2. Water solubility index (WSI) and water absorption index (WAI) at different temperatures $\left(25-90^{\circ} \mathrm{C}\right)$, and oil absorption index (OAI) at $25^{\circ} \mathrm{C}$ of freeze-dried açaí pulp.

\begin{tabular}{cccc}
\hline $\begin{array}{c}\text { Temperature } \\
\left({ }^{\circ} \mathrm{C}\right)\end{array}$ & $\begin{array}{c}\mathrm{WAI}^{*} \\
(\mathrm{~g} / 100 \mathrm{~g})\end{array}$ & $\begin{array}{c}\mathrm{OAI}^{*} \\
(\mathrm{~g} \text { precipitate/100 g) }\end{array}$ & $\begin{array}{c}\mathrm{WSI}^{*} \\
(\%)\end{array}$ \\
\hline 25 & $3.3 \pm 0.1^{\mathrm{d}}$ & $2.8 \pm 0.04$ & $18.3 \pm 0.3^{\mathrm{d}}$ \\
60 & $3.2 \pm 0.1^{\mathrm{d}}$ & - & $21.7 \pm 0.6^{\mathrm{c}}$ \\
70 & $4.2 \pm 0.06^{\mathrm{c}}$ & - & $22.7 \pm 0.5^{\mathrm{cb}}$ \\
80 & $4.5 \pm 0.06^{\mathrm{b}}$ & - & $24.1 \pm 0.9^{\mathrm{b}}$ \\
90 & $4.6 \pm 0.2^{\mathrm{a}}$ & - & $26.4 \pm 0.4^{\mathrm{a}}$ \\
\hline
\end{tabular}

Data are mean followed by standard deviation $(n=9) ;{ }^{*}$ Values expressed on a dry weight basis. Means followed by different letters in a column differ statistically according with the Tukey's test $(\mathrm{p}<0.05)$.

smaller particles float on the surface of water, causing a problem for reconstitution of the powder.

\section{Conclusion}

Freeze-dried açaí pulp (FDAP) showed course granulometry, a spongey appearance and was highly porous. The low enthalpy value and the peaks obtained on the X-ray diffractogram characterized FDAP as being an amorphous material, despite the sugar crystallization that occurred due to the freeze-drying process. FDAP showed high nutritional value, mainly due to its relevant content of lipids, fiber, protein and minerals, which made of it a food with high energy density. In addition, it showed significant total phenolic compounds content, including anthocyanins, allowing for allegations of functional properties. Thus, the consumption of FDAP should be encouraged and also its use by the industry in order to develop new food products.

\section{Acknowledgements}

The authors are grateful for the support from Universidade Federal de Goiás (UFG), CAPES (Coordenação de Aperfeiçoamento de Pessoal de Nível Superior - Finance code 001), CNPq (Conselho Nacional de Desenvolvimento Científico e Tecnológico), and FAPEG (Fundação de Amparo à Pesquisa do Estado de Goiás).

\section{References}

Abbas, O., Compère, G., Larondelle, Y., Pompeu, D., Rogez, H., \& Baeten, V. (2017). Phenolic compound explorer: a mid-infrared spectroscopy database. Vibrational Spectroscopy, 92, 111-118. http:// dx.doi.org/10.1016/j.vibspec.2017.05.008.

Alexandre, D., Cunha, R. L., \& Hubinger, M. D. (2004). Preservation of the assai pulp through the application of obstacles. Food Science and Technology (Campinas), 24(1), 114-119. http://dx.doi.org/10.1590/ S0101-20612004000100021.

Anderson, R. A., Conway, H. F., \& Peplinski, A. J. (1970). Gelatinization of corn grits by roll cooking, extrusion cooking and steaming. Starch, 22(4), 130-135. http://dx.doi.org/10.1002/star.19700220408.

Anjos, O., Campos, M. G., Ruiz, P. C., \& Antunes, P. (2015). Application of FTIR-ATR spectroscopy to the quantification of sugar in honey. Food Chemistry, 169, 218-223. http://dx.doi.org/10.1016/j. foodchem.2014.07.138. PMid:25236219. 
Arslan, D. (2015). Effects of degradation preventive agents on storage stability of anthocyanins in sour cherry concentrate. Agronomy Research (Tartu), 13(4), 892-899.

Association of Official Analytical Chemists - AOAC. (2016). Official methods of analysis of the Association of Official Analytical Chemists International (20th ed.). Gaithersburg: AOAC.

Bessada, S. M. F., Barreira, J. C. M., \& Oliveira, M. B. P. P. (2015). Asteraceae species with most prominent bioactivity and their potential applications: a review. Industrial Crops and Products, 76, 604-615. http://dx.doi.org/10.1016/j.indcrop.2015.07.073.

Bhanja Dey, T., Chakraborty, S., Jain, K. K., Sharma, A., \& Kuhad, R. C. (2016). Antioxidant phenolics and their microbial production by submerged and solid state fermentation process: a review. Trends in Food Science \& Technology, 53, 60-74. http://dx.doi.org/10.1016/j. tifs.2016.04.007.

Borges, G. S. C., Vieira, F. G. K., Copetti, C., Gonzaga, L. V., Zambiazi, R. C., Mancini, J. Fo., \& Fett, R. (2011). Chemical characterization, bioactive compounds, and antioxidant capacity of jussara (Euterpe edulis) fruit from the Atlantic Forest in southern Brazil. Food Research International, 44(7), 2128-2133. http://dx.doi.org/10.1016/j. foodres.2010.12.006.

Brand-Williams, W., Cuvelier, M. E., \& Berset, C. (1995). Use of a free radical method to evaluate antioxidant activity. LebensmittelWissenschaft + Technologie, 28(1), 25-30. http://dx.doi.org/10.1016/ S0023-6438(95)80008-5.

Brasil. Ministério da Agricultura, Pecuária e Abastecimento - MAPA. (2000, January 7). Aprova o Regulamento Técnico Geral para fixação dos Padrões de Identidade e Qualidade para polpa de fruta (Instrução Normativa No 1, de 07 de janeiro de 2000). Diário Oficial [da] República Federativa do Brasil, seção 1.

Caldeira Silva, F., Rossi, D. A., Cardoso, V. L., Reis, M. H. M., \& Reis, M. H. M. (2016). Stabilization of açaí (Euterpe oleracea Mart) juice by the microfiltration process. Acta Scientiarum, 38(1), 7. http:// dx.doi.org/10.4025/actascitechnol.v38i1.27037.

Castillo, Y. M., Lares, M., Gutiérrez, R. H., Hernández, M. S., \& Pablo Fernández-Trujillo, J. (2013). Bioactive compounds of asai palm fruit and their impact on health. Foods, 1, 1-9. http://dx.doi.org/10.3390/ foods10x000x.

Castro, C. A., Natali, A. J., Cardoso, L. M., Ferreira-Machado, A. B., Novello, A. A., Silva, K. A., Tafuri, N. F., da Matta, S. L. P., Pedrosa, M. L., \& Peluzio, M. C. G.. (2014). Aerobic exercise and not a diet supplemented with jussara açaí (Euterpe edulis Martius) alters hepatic oxidative and inflammatory biomarkers in ApoE-deficient mice. British Journal of Nutrition, 112(03), 285-294. http://dx.doi. org/10.1017/S000711451400083X. PMid:24787366.

Chen, T., Mackie, C., Candian, A., Lee, T. J., \& Tielens, A. G. G. M. (2018). Anharmonicity and the infrared emission spectrum of highly excited polycyclic aromatic hydrocarbons. Astronomy \& Astrophysics, 618, A49. http://dx.doi.org/10.1051/0004-6361/201833731.

Costa, R. G., Andreola, K., Andrade Mattietto, R., Faria, L. J. G., \& Taranto, O. P. (2015). Effect of operating conditions on the yield and quality of açai (Euterpe oleracea Mart.) powder produced in spouted bed. Lebensmittel-Wissenschaft + Technologie, 64(2), 11961203. http://dx.doi.org/10.1016/j.lwt.2015.07.027.

Coutinho, R. M. P., Aparecida, E., Fontes, F., Vieira, L. M., Barros, F. A. R., Carvalho, A. F., \& Stringheta, P. C. (2017). Physicochemical and microbiological characterization and antioxidant capacity of açaí pulps marketed in the states of Minas Gerais and Pará, Brazil. Ciência Rural, 47(1), 1-6. http://dx.doi.org/10.1590/0103-8478cr20151172.

Daiuto, É. R., Tremocoldi, M. A., Alencar, S. M., Vieites, R. L., \& Minarelli, P. H. (2014). Chemical composition and antioxidant activity of the pulp, peel and by products of avocado 'hass'. Revista Brasileira de Fruticultura, 36(2), 417-424. http://dx.doi.org/10.1590/01002945-102/13.

Eng Khoo, H., Azlan, A., Teng Tang, S., \& Meng Lim, S. (2017). Anthocyanidins and anthocyanins: Colored pigments as food, pharmaceutical ingredients, and the potential health benefits. Food \& Nutrition Research, 61(1361779), 1-21. http://dx.doi.org/10.1080 /16546628.2017.1361779. PMid:28970777.

Engels, G. (2010). Açaí. HerbalGram, 86, 1-2. Retrieved from http:// cms.herbalgram.org/herbalgram/issue86/article3511.html?ts=1558 701536\&signature $=1 \mathrm{c} 97419 \mathrm{a} 95 \mathrm{ddae} 5 \mathrm{f306f19} \mathrm{c} 7 \mathrm{faad} 5784$

Fregonesi, B. M., Yokosawa, C. E., Okada, I. A., Massafera, G., Costa, T. M. B., \& Prado, S. P. T. (2010). Frozen açai pulp. Study on the nutritional and physical-chemical characteristics, and microscopic and product labelling analyses. Revista do Instituto Adolfo Lutz, 69(3), 387-395.

Gaidhani, K. A., Harwalkar, M., Bhambere, D., \& Nirgude, P. S. (2015). Lyophilization/ Freeze drying - A review. World Journal of Pharmaceutical Research, 4(8), 516-543.

Garzón, G. A., Narváez-Cuenca, C. E., Vincken, J. P., \& Gruppen, H. (2017). Polyphenolic composition and antioxidant activity of açai (Euterpe oleracea Mart.) from Colombia. Food Chemistry, 217, 364-372. http://dx.doi.org/10.1016/j.foodchem.2016.08.107. PMid:27664647.

Harnkarnsujarit, N., \& Charoenrein, S. (2011). Effect of water activity on sugar crystallization and $\beta$-carotene stability of freeze-dried mango powder. Journal of Food Engineering, 105(4), 592-598. http://dx.doi. org/10.1016/j.jfoodeng.2011.03.026.

Henderson, S. M., \& Perry, R. L. (1976). Agricultural process engineering (3rd ed., Chap. 6: size reduction, p. 130-159). Westport: AVI Publishing.

Hidalgo, A., Fongaro, L., \& Brandolini, A. (2014). Wheat flour granulometry determines colour perception. Food Research International, 64, 363370. http://dx.doi.org/10.1016/j.foodres.2014.06.050. PMid:30011662.

Hidalgo, G.-I., \& Almajano, M. P. (2017). Red fruits: Extraction of antioxidants, phenolic content, and radical scavenging determination: a review. Antioxidants, 6(1), 7. http://dx.doi.org/10.3390/antiox6010007. PMid:28106822.

Ishwarya, S. P., Anandharamakrishnan, C., \& Stapley, A. G. F. (2015). Spray-freeze-drying: a novel process for the drying of foods and bioproducts. Trends in Food Science \& Technology, 41(2), 161-181. http://dx.doi.org/10.1016/j.tifs.2014.10.008.

Jafari, S. M., Ghalegi Ghalenoei, M., \& Dehnad, D. (2017). Influence of spray drying on water solubility index, apparent density, and anthocyanin content of pomegranate juice powder. Powder Technology, 311, 59-65. http://dx.doi.org/10.1016/j.powtec.2017.01.070.

Lago, E. S., Gomes, E., \& Silva, R. (2006). Production of jambolan (Syzygium cumini Lamarck) jelly: processing, physical-chemical properties and sensory evaluation. Food Science and Technology (Campinas), 26(4), 847-852. http://dx.doi.org/10.1590/S010120612006000400021.

Leopold, J. A. (2015). Antioxidants and coronary artery disease: from pathophysiology to preventive therapy. Coronary Artery Disease, 26(2), 176-183. http://dx.doi.org/10.1097/MCA.0000000000000187. PMid:25369999.

Lili, L., Huan, W., Guangyue, R., Xu, D., Dan, L., \& Guangjun, Y. (2015). Effects of freeze-drying and spray drying processes on functional properties of phosphorylation of egg white protein. International Journal of Agricultural and Biological Engineering, 8(4), 116-123. http://dx.doi.org/10.25165/IJABE.V8I4.1942.

Liu, W., Yin, D., Li, N., Hou, X., Wang, D., Li, D., \& Liu, J. (2016). Influence of environmental factors on the active substance production and antioxidant activity in Potentilla fruticosa L. and its 
quality assessment. Scientific Reports, 6(28591), 1-18. http://dx.doi. org/10.1038/srep28591. PMid:27373366.

McGuire, R. G. (1992). Reporting of objective color measurements. HortScience, 27(12), 1254-1255. http://dx.doi.org/10.21273/ HORTSCI.27.12.1254.

Menezes, E. M. S., Torres, A. T., \& Sabaa Srur, A. U. (2008). Lyophilized açaí pulp $(<\mathrm{I}>$ Euterpe oleracea $</ \mathrm{I}>$ Mart. $)$ nutritional value. Acta Amazonica, 38(2), 311-316. http://dx.doi.org/10.1590/S004459672008000200014.

Mensink, M. A., Frijlink, H. W., van der Voort Maarschalk, K., \& Hinrichs, W. L. J. (2017). How sugars protect proteins in the solid state and during drying (review): mechanisms of stabilization in relation to stress conditions. European Journal of Pharmaceutics and Biopharmaceutics, 114, 288-295. http://dx.doi.org/10.1016/j. ejpb.2017.01.024. PMid:28189621.

Miller, G. L. (1959). Use of dinitrosalicylic acid reagent for determination of reducing sugar. Analytical Chemistry, 31(3), 426-428. http://dx.doi. org/10.1021/ac60147a030.

Montalvo-González, E., Aguilar-Hernández, G., Hernández-Cázares, A. S., Ruiz-López, I. I., Pérez-Silva, A., Hernández-Torres, J., \& VivarVera, M. (2018). Production, chemical, physical and technological properties of antioxidant dietary fiber from pineapple pomace and effect as ingredient in sausages. CYTA: Journal of Food, 16(1), 831839. http://dx.doi.org/10.1080/19476337.2018.1465125.

Moura, C., Reis, A. S., Silva, L. D., Lima, V. A., Oldoni, T. L. C., Pereira, C., \& Carpes, S. T. (2018). Optimization of phenolic compounds extraction with antioxidant activity from açaí, blueberry and goji berry using response surface methodology. Emirates Journal of Food and Agriculture, 30(3), 180-189. http://dx.doi.org/10.9755/ ejfa.2018.v30.i3.1639.

Musingarabwi, D. M., Nieuwoudt, H. H., Young, P. R., Eyéghè-Bickong, H. A., \& Vivier, M. A. (2016). A rapid qualitative and quantitative evaluation of grape berries at various stages of development using Fourier-transform infrared spectroscopy and multivariate data analysis. Food Chemistry, 190, 253-262. http://dx.doi.org/10.1016/j. foodchem.2015.05.080. PMid:26212968.

Nara, S., \& Komiya, T. (1983). Studies on the relationship between water-satured state and crystallinity by the diffraction method for moistened potato starch. Starch, 35(12), 407-410. http://dx.doi. org/10.1002/star.19830351202.

Neida, S., \& Elba, S. (2007). Characterization of the acai or mancada (Euterpe oleracea Mart.): a fruit of the Amazon. Archivos Latinoamericanos de Nutricion, 57(1), 94-98. PMid:17824205.

Nimse, S. B., \& Pal, D. (2015). Free radicals, natural antioxidants, and their reaction mechanisms. RSC Advances, 5(35), 27986-28006. http://dx.doi.org/10.1039/C4RA13315C.

Núñez-Sánchez, N., Martínez-Marín, A. L., Polvillo, O., FernándezCabanás, V. M., Carrizosa, J., Urrutia, B., \& Serradilla, J. M. (2016). Near Infrared Spectroscopy (NIRS) for the determination of the milk fat fatty acid profile of goats. Food Chemistry, 190, 244-252. http://dx.doi.org/10.1016/j.foodchem.2015.05.083. PMid:26212967.

Nurhadi, B., Sukri, N., Sugandi, W. K., Widanti, A. P., Restiani, R., Noflianrini, Z., Rezaharsamto, B., \& Herudiyanto, M. (2018). Comparison of crystallized coconut sugar produced by traditional method and amorphous coconut sugar formed by two drying methods: Vacuum drying and spray drying. International Journal of Food Properties, 21(1), 2339-2354. http://dx.doi.org/10.1080/10 942912.2018.1517781.
Okan, O. T., Deniz, I., Yayli, N., Sat, I. G., Oz, M., \& Hatipoglu Serdar, G. (2018). Antioxidant activity, sugar content and phenolic profiling of blueberries cultivars: a comprehensive comparison. Notulae Botanicae Horti Agrobotanici Cluj-Napoca, 46(2), 639-652. http:// dx.doi.org/10.15835/nbha46211120.

Oliveira, L. C., Souza, S. O., \& Mamede, M. E. O. (2011). Evaluation of physicochemical and colorimetric characteristics of fine wines from two main vineyards regions of Brazil. Revista do Instituto Adolfo Lutz, 70(2), 158-167.

Pereira, V. A., Arruda, I. N. Q., \& Stefani, R. (2015). Active chitosan/ PVA films with anthocyanins from Brassica oleracea (Red Cabbage) as Time-Temperature Indicators for application in intelligent food packaging. Food Hydrocolloids, 43, 180-188. http://dx.doi. org/10.1016/j.foodhyd.2014.05.014.

Rajkumar, G., Shanmugam, S., Galvâo, M. S., Dutra Sandes, R. D., Leite Neta, M. T. S., Narain, N., \& Mujumdar, A. S. (2017). Comparative evaluation of physical properties and volatiles profile of cabbages subjected to hot air and freeze drying. LWT, 80, 501-509. http:// dx.doi.org/10.1016/j.lwt.2017.03.020.

Sablani, S. S. (2015). Freezing of fruis and impact on anthocyanins. In V. R. Preedy (Ed.), Processing and impact on active components in food (pp. 147-156). Waltham: Academic Press. http://dx.doi. org/10.1016/B978-0-12-404699-3.00018-4.

Santos, V. S., Bisen-Hersh, E., Yu, Y., Cabral, I. S. R., Nardini, V., Culbreth, M., et al (2014). Anthocyanin-rich açaí (Euterpe oleracea Mart.) extract attenuates manganese-induced oxidative stress in rat primary astrocyte cultures. Journal of Toxicology and Environmental Health. Part A., 77(7), 390-404. http://dx.doi.org/10.1080/1528739 4.2014.880392. PMid:24617543.

Silveira, T. F. F., Souza, T. C. L., Carvalho, A. V., Ribeiro, A. B., Kuhnle, G. G. C., \& Godoy, H. T. (2017). White açaí juice (Euterpe oleracea): phenolic composition by LC-ESI-MS/MS, antioxidant capacity and inhibition effect on the formation of colorectal cancer related compounds. Journal of Functional Foods, 36, 215-223. http://dx.doi. org/10.1016/j.jff.2017.07.001.

Singleton, V. L., \& Rossi, J. A. Jr. (1965). Colorimetry of total phenolics with phosphomolybdic-phosphotungstic acid reagents. American Journal of Enology and Viticulture, 16(3), 144-158. http://dx.doi. org/10.12691/ijebb-2-1-5.

Siqueira, A. P. S., Santos, K. F., Barbosa, T. A., Freire, L. A. S., \& Camêlo, Y. A. (2018). Technological differences between açai and juçara pulps and their sorbets. Brazilian Journal of Food Technology, 21(e2017047), 1-6. http://dx.doi.org/10.1590/1981-6723.4717.

South African Bureau of Standards - SABS. (1990). Determination of fineness modules of fine aggregates. (Method 829). Pretoria: SABS.

StatSoft Inc. (2010). Statistica (Data analysis software system) version 10.0. Tulsa: StatSoft Inc.

Virginia Department of Transportation - VDT. (2015). Sieve analysis and fineness modulus. Richmond: VDT.

World Resources Institute - WRI. (2017). Brazil's fruitful example: açaí. Retrieved from https://www.wri.org/blog/2017/10/brazilsfruitful-example-acai

Wrolstad, R. E., Durst, R. W., \& Lee, J. (2005). Tracking color and pigment changes in anthocyanin products. Trends in Food Science \& Technology, 16(9), 423-428. http://dx.doi.org/10.1016/j.tifs.2005.03.019.

Yamaguchi, K. K. L., Pereira, L. F. R., Lamarão, C. V., Lima, E. S., \& Veiga-Junior, V. F. (2015). Amazon acai: chemistry and biological activities: a review. Food Chemistry, 179, 137-151. http://dx.doi. org/10.1016/j.foodchem.2015.01.055. PMid:25722148. 